\title{
Integration interaction of Russia and China in the conditions of digital transformation of the economy
}

\author{
Yulia Vertakova ${ }^{1, *}$, Olga Kryzhanovskaya ${ }^{1}$, Ding Shuyi ${ }^{1}$ and Liu Yayi ${ }^{1}$ \\ ${ }^{1}$ Southwest State University, 305040, 94, 50 Let Oktyabrya str., Kursk, Russian Federation
}

\begin{abstract}
In the context of the active digitalization of the economic space, a fundamental transformation of thinking, methodological approaches to the development and implementation of public policy and its tools for building effective integration interaction to achieve strategic advantages in a strategic perspective is taking place. It is these circumstances that determine the relevance of the research topic. The purpose of the publication is to study the features of the integration interaction between Russia and China in the context of the digital transformation of the economy. The study is based on the modern methodology of economic analysis, performed using the deductive and inductive approaches, using the methods of comparative, structural-logical, statistical analysis. As a result of the study, it was proved that the development of long-term relations between Russia and China is based on the virtual exchange of resources in the context of the digital transformation of the economy.
\end{abstract}

\section{Introduction}

The purpose of the study is to determine the need to solve the following problems: to analyze the trade between Russia and China, to study the structure of exports and imports of Russia and China; outline the main guidelines of the "One Belt - One Way" policy and its impact on globalization and regional integration.

In 2018, Russia's trade with China amounted to $\$ 108,283,490,396$, an increase of $24.51 \%(\$ 21,319,146,670)$ compared to 2017 . China's share in the foreign trade turnover of Russia in 2018 amounted to $15.7362 \%$ compared to $14.8899 \%$ in 2017. In 2018, China took the 1st place in the share of Russian goods turnover (in 2017, it also took 1st place). China's share in Russian exports in 2018 amounted to $12.4600 \%$ compared to $10.9000 \%$ in 2017. According to the share of Russian exports in 2018, China took 1st place (in 2017 also 1st place). The share of China in Russia's imports in 2018 amounted to $21.9264 \%$ compared to $21.1671 \%$ in 2017. According to the share of Russian imports in 2018, China took 1st place (in 2017 - also 1st place)

The structure of exports and imports of Russia and China in 2018 is presented in table 1.

\footnotetext{
* Corresponding author: vertakova7@ yandex.ru
} 
Table 1. The Structure of exports and imports of Russia and China in 2018

\begin{tabular}{|c|c|}
\hline Russia's exports to China & Russia's imports from China \\
\hline $\begin{array}{l}\text { In the structure of Russia's exports to China in } \\
2018 \text { (and in 2017), the main share of supplies } \\
\text { fell on the following types of goods: } \\
\text { - Mineral products - } 76.19 \% \text { of Russia's total } \\
\text { exports to China (in } 2017-67.80 \% \text { ); } \\
-\quad \text { Wood and pulp and paper products }-8.62 \% \\
\text { of Russia's total exports to China (10.71\% in } \\
2017 \text { ); } \\
-\quad \text { Food products and agricultural raw } \\
\text { materials - 4.50\% of Russia's total exports to } \\
\text { China (4.56\% in 2017); } \\
-\quad \text { Machinery, equipment and vehicles - } \\
3.26 \% \text { of Russia's total exports to China }(6.86 \% \\
\text { in } 2017 \text { ); } \\
-\quad \text { Chemical industry products - } 2.83 \% \text { of } \\
\text { Russia's total exports to China (4.35\% in } 2017) \text {; } \\
-\quad \text { Metals and products from them - } 2.38 \% \text { of } \\
\text { Russia's total exports to China (1.65\% in 2017) }\end{array}$ & $\begin{array}{l}\text { In the structure of Russia's imports from } \\
\text { China in } 2018 \text { (and in 2017), the main share } \\
\text { of supplies fell on the following types of } \\
\text { goods: } \\
-\quad \text { Machinery, equipment and vehicles - } \\
57.12 \% \text { of Russia's total imports from China } \\
(58.95 \% \text { in 2017); } \\
-\quad \text { Textiles and shoes - } 11.17 \% \text { of Russia's } \\
\text { total imports from China (in } 2017-11.13 \%) \text {; } \\
-\quad \text { Chemical industry products }-9.91 \% \text { of } \\
\text { Russia's total imports from China ( } 8.97 \% \text { in } \\
2017) \text {; } \\
-\quad \text { Metals and products from them - 7.75\% } \\
\text { of Russia's total imports from China (7.09\% } \\
\text { in 2017); } \\
-\quad \text { Food products and agricultural raw } \\
\text { materials - 3.64\% of Russia's total imports } \\
\text { from China (3.68\% in 2017). }\end{array}$ \\
\hline $\begin{array}{l}\text { The largest gains in Russia's exports to China } \\
\text { in } 2018 \text { over } 2017 \text { were recorded for the } \\
\text { following product groups: } \\
-\quad \text { Mineral fuel, oil and products of their } \\
\text { distillation; bituminous substances; mineral } \\
\text { waxes - an increase of } \$ 15,962,979,666 \text {; } \\
-\quad \text { Copper and articles thereof - an increase of } \\
\$ 614,626,320 \text {; } \\
-\quad \text { Fish and crustaceans, molluscs and other } \\
\text { aquatic invertebrates - an increase of } \$ \\
403,817,695 \text {; } \\
-\quad \text { Ores, slag and ash - an increase of } \$ \\
352,878,811 \text {; } \\
-\quad \text { Wood and wood products; charcoal - an } \\
\text { increase of } \$ 287,914,472 \text {; } \\
-\quad \text { Pulp from wood or from other fibrous } \\
\text { cellulosic materials; recoverable paper or } \\
\text { paperboard (waste paper and waste) - an increase } \\
\text { of } \$ 265,768,910 \text {. }\end{array}$ & $\begin{array}{l}\text { The largest gains in Russia's imports from } \\
\text { China in } 2018 \text { over } 2017 \text { were recorded for } \\
\text { the following product groups: } \\
-\quad \text { Electric machines and equipment, their } \\
\text { parts; sound recording and reproducing } \\
\text { apparatus, apparatus for recording and } \\
\text { reproducing television images and sound, } \\
\text { parts and accessories thereof - an increase of } \\
\$ 2,578,401,383 \text {; } \\
-\quad \text { Plastics and articles thereof - an increase } \\
\text { of } \$ 289,000197 \text {; } \\
-\quad \text { Ferrous metal products - an increase of } \\
\$ 265,388,208 \text {; } \\
-\quad \text { Ground transportation means, except for } \\
\text { railway or tram rolling stock, and their parts } \\
\text { and accessories - an increase of } \$ \\
243,114,433 \text {; } \\
-\quad \text { Organic chemical compounds - an } \\
\text { increase of } \$ 220,716,369 ; \\
-\quad \text { Shoes, leggings and similar products; } \\
\text { their details are an increase of } \$ 166,860,539 \text {. }\end{array}$ \\
\hline $\begin{array}{l}\text { The largest declines in Russia's exports to } \\
\text { China in } 2018 \text { over } 2017 \text { were recorded for the } \\
\text { following product groups: } \\
\text { - Electric machines and equipment, their } \\
\text { parts; sound recording and reproducing } \\
\text { apparatus, apparatus for recording and } \\
\text { reproducing television images and sound, parts } \\
\text { and accessories thereof - a decrease of } \$ \\
531,053,427 \text {; } \\
\text { - Ground transportation means, except for } \\
\text { railway or tram rolling stock, and their parts and } \\
\text { accessories - a decrease of } \$ 223,788,356 \text {. }\end{array}$ & $\begin{array}{l}\text { The largest declines in Russia's imports } \\
\text { from China in } 2018 \text { over } 2017 \text { were recorded } \\
\text { for the following product groups: } \\
\text { Nuclear reactors, boilers, equipment and } \\
\text { mechanical devices; parts thereof - a } \\
\text { decrease of } \$ 1,566,231,552 \text {. }\end{array}$ \\
\hline
\end{tabular}

Source: prepared by the official website Foreign Trade of Russia based on data from the Federal Customs Service of Russia 
The development of long-term relations between Russia and China is also expected in a strategic perspective based on a virtual exchange of resources in the context of digital globalization.

In the context of digital globalization, such Chinese authors as Wang Junyi, Jin Lingbo, Yuan Pinghong and others participate.

Researchers of the main trends in the development of digital technologies in Russia and abroad apply modern technologies in which such Russian scientists as Babkin A.V., Vertakova Yu. V., Kuladzhi T.V., Murtazaev S.A.Yu. Plotnikov V.A. Tashenova L.V.

Improving cross-border e-commerce and cooperation in the field of the digital economy based on the documents "Belt and Road" is devoted to the work of Chinese authors such as Zhang Jian, Yang Song, Liu Wei, Zhang Hui, Zhao Jinping, Luo Yuze and others.

Among the Chinese authors who investigated the current state and identified directions for the future development of technology, the blockchain should be noted by U. Yuanwen, Zhao Godong, Liu Wenxue, Yuan Yong, Wang Feiyue, Wang Shuo, etc.

\section{Results and Discussion}

The development of international cooperation based on innovative intelligent technologies.

1. Prerequisites for international cooperation on the example of "Belts and Roads". The historical need of the project "One belt - one way"

Economic globalization is a hallmark modern development. However, globalization has not always been in a stage of dynamic development since its inception. The development of the global economy has undergone twisting processes. Since the 1950s, the total economic volume in Asia has been growing rapidly, and the share of European and American economies has been declining every year. At the same time, the dynamic development of the population on all continents of the world shows similar patterns: the share of the European population in the world is declining year by year, and the proportion of the population in the Americas has stabilized. According to the database of the United Nations Conference on Trade and Development, as of 2015, Europe's share of the world has declined to $10.1 \%$, the population of North and South America is $13.5 \%$ of the world's population, and the population of Asia is $59.8 \%$ of the world. Economic development is inseparable from labor support. Although most of the European and American economies are developed, in the future the growth of the population of the workforce will become less, which does not contribute to its long-term sustainable development. Although China has always been the most populous country, its share in the global population is still slowly growing. As the country with the largest population, although demographic dividends are gradually decreasing, it is still a country with relatively rich labor resources in the world. Moreover, compared with India, the second largest country in terms of population, China's labor force is better. According to the World Bank database, the adult literacy rate in India in 2015 was only $72.22 \%$, and in China - $96.36 \%$. Today's global economy is experiencing a new shift in the industrial center, accompanied by a growing demand for quality labor. China proposed the "Belts and Roads Initiative" - to create a public platform for the exchange of experience and cooperation between developed and developing countries, on the one hand, through dividends of its high-quality talents, it will form an industry and value chain, and will also contribute to the development of developing countries. Demographic benefits are transferred to human resources and capital.

From 1960 to 1975 , it was a relatively fast period of globalization, in which the average annual growth rate was $2 \%$. This stage shaped the Japanese economy, and Japan led the rapid development of the East Asian economy. From 1975 to 1989, slow growth was observed, with an average annual growth rate of $1.1 \%$. 
Achieving American Reaganism has also become the culmination of the advancement of neoliberalism. Japan did not take advantage of the strategic opportunity phase at this stage. The United States promoted Reaganism, resulting in the loss of two decades in Japan's economic development. From 1990 to 2007, globalization entered an explosive growth cycle, reaching an average of $2.2 \%$ per year. At this stage, China took the opportunity to move from a relatively backward country to the world's second largest economy. After 2008, the global economy showed negative growth $(-0.2 \%)$. In the context of the repetition of globalization, especially when the trend of "anti-globalization" is becoming more serious after 2008, if China takes the initiative, it will create a new stage of globalization and propose a new globalization.

2. China's banking industry indicators in the belt and road

Five state-owned commercial banks and two joint-stock commercial banks dominate the Chinese banking industry. At the end of 2017, about 22 Chinese banks opened 1,353 branches abroad in 63 countries and regions (Table 2).

Table 2. Countries and regions covered by foreign institutions of Chinese banks (2017)

\begin{tabular}{|c|c|c|c|c|c|c|}
\hline $\begin{array}{c}\text { Leading } \\
\text { Transnational } \\
\text { Banks of China }\end{array}$ & $\begin{array}{l}\text { Asia-Pacific } \\
\text { (except Hong } \\
\text { Kong, } \\
\text { Macau and } \\
\text { Taiwan) }\end{array}$ & $\begin{array}{l}\text { Hong } \\
\text { Kong, } \\
\text { Macau } \\
\text { and } \\
\text { Taiwan }\end{array}$ & Europe & America & Africa & Total \\
\hline $\begin{array}{l}\text { Industrial and } \\
\text { commercial bank of } \\
\text { china }\end{array}$ & 19 & 2 & 11 & 6 & 1 & 42 \\
\hline $\begin{array}{l}\text { Agricultural bank of } \\
\text { China }\end{array}$ & 7 & 2 & 4 & 2 & 0 & 15 \\
\hline Bank of China & 18 & 3 & 17 & 6 & 7 & 51 \\
\hline $\begin{array}{l}\text { China construction } \\
\text { bank }\end{array}$ & 9 & 3 & 11 & 5 & 1 & 29 \\
\hline $\begin{array}{l}\text { Bank of } \\
\text { communications }\end{array}$ & 6 & 3 & 3 & 3 & 0 & 16 \\
\hline China merchants & 1 & 1 & 2 & 1 & 0 & 5 \\
\hline China citic bank & 2 & 1 & 1 & 0 & 0 & 4 \\
\hline
\end{tabular}

Source: People's Bank of China Annual Report

The number of employees of foreign institutions of large commercial banks is about 1,279 people. Despite the fact that there is still a significant gap compared to large foreign banks, the opportunities for China's international banking industry are constantly improving due to the stable pace of development of the national economy and the deep development of the One Belt, One Road strategy, as well as the emergence of some new ones. advantages.

Description of the state of transnational banks. Firstly, the network of foreign branches continues to expand, and there are big differences between different types of banks. Five large multinational banks cover a large number of countries and regions, especially the Bank of China and the Industrial and Commercial Bank, covering 51 and 42 countries, respectively. They are mainly located in the Asia-Pacific region and Europe, and are expanding due to the participation in the share capital of local financial institutions. Foreign bank branches currently cover the five leading international financial centers of the world and the economy, and are mainly distributed in Hong Kong, Macau, Taiwan and Southeast Asia, where a more reliable regime of foreign expansion has been achieved [1].

Among foreign institutions of Chinese banks, attention to the development of "One Belt - One Road" is especially important. By the end of 2017, nine Chinese banks had created 
62 first-tier branches in 26 countries along this project, which is three years more than the previous year [2]. Large commercial banks are located "along the way" in the institutions created earlier, while the expansion of coverage of countries and regions occurs due to the opening of new branches and increasing the global financial services opportunities of Chinese banks. Reserves are being formed to ensure financing of projects oriented along the One Belt - One Road project [3]. So far, several branches have been opened, but they will make full use of their business financing opportunities using appropriate mechanisms to provide diversified and comprehensive financial services (Table 3).

Table 3. The position of Chinese banks in the project "One belt - One road"

\begin{tabular}{|c|c|c|}
\hline Banks & Institutional layout & Business development \\
\hline $\begin{array}{l}\text { Industrial and } \\
\text { commercial bank } \\
\text { of china }\end{array}$ & $\begin{array}{l}127 \text { organizations in } 18 \\
\text { countries along the way of } \\
\text { the project }\end{array}$ & $\begin{array}{l}\text { Loans issued in the amount of } 23.5 \text { billion } \\
\text { US dollars, } 212 \text { support projects and more } \\
\text { than } 200 \text { reserve projects }\end{array}$ \\
\hline $\begin{array}{l}\text { Agricultural bank } \\
\text { of china }\end{array}$ & $\begin{array}{l}7 \text { organizations in } 4 \\
\text { countries along the way of } \\
\text { the project }\end{array}$ & $\begin{array}{l}\text { Infrastructure loans in the amount of } \$ \\
350 \text { million, cross-border mergers and } \\
\text { acquisitions in the amount of } \$ 93.2 \\
\text { million, trade financing in the amount of } \$ \\
2.673 \text { billion and international settlements } \\
\text { in the amount of } \$ 71.147 \text { billion }\end{array}$ \\
\hline Bank of china & Covering 19 countries & $\begin{array}{l}420 \text { large projects followed with a total } \\
\text { investment of more than } 400 \text { billion US } \\
\text { dollars and completed various credit lines } \\
\text { of more than } 60 \text { billion US dollars. }\end{array}$ \\
\hline $\begin{array}{l}\text { China construction } \\
\text { bank }\end{array}$ & $\begin{array}{l}20 \text { organizations in } 5 \\
\text { countries along the way of } \\
\text { the project }\end{array}$ & $\begin{array}{l}25 \text { major projects worth } 45.4 \text { billion US } \\
\text { dollars }\end{array}$ \\
\hline $\begin{array}{l}\text { Bank of } \\
\text { communications }\end{array}$ & $\begin{array}{l}\text { Establishment of } \\
\text { institutions in three } \\
\text { countries along the way of } \\
\text { the project }\end{array}$ & $\begin{array}{l}4 \text { projects were completed for } \$ 740 \\
\text { million, three projects of medium and } \\
\text { long-term financing totaling } \$ 440 \text { million } \\
\text { were completed and credit support was } \\
\text { provided to } 37 \text { cross-border projects }\end{array}$ \\
\hline $\begin{array}{l}\text { China merchants } \\
\text { bank }\end{array}$ & $\begin{array}{l}\text { Offshore branch - covers } \\
\text { the main financial centers }\end{array}$ & $\begin{array}{l}139 \text { projects have been planned, of which } \\
83 \text { projects have been completed, the } \\
\text { investment on them amounted to } 37.351 \\
\text { billion US dollars, the volume of factoring } \\
\text { services }-1.12 \text { billion US dollars, and } \\
\text { loans }-3.188 \text { billion US dollars. }\end{array}$ \\
\hline China citic bank & $\begin{array}{l}\text { Established institution in } 1 \\
\text { country along the way of } \\
\text { the project }\end{array}$ & $\begin{array}{l}\text { The formation of great synergy through } \\
\text { major transactions and the creation of a } \\
\text { large investment bank to form a } \\
\text { diversified integrated system of financial } \\
\text { products }\end{array}$ \\
\hline
\end{tabular}

Source: People's Bank of China Annual Report

Secondly, the assets and profits of foreign institutions of transnational banks increased every year, but there remains a need to increase business profitability. At the end of 2017, the foreign assets of five large commercial banks amounted to 5.6 trillion. RMB, of which ICBC and CCB assets were at the top, accounting for $8.8 \%$ and $6.6 \%$ of the total assets of the banks themselves. The largest, about 26\%, share of foreign institutions reflects the relatively high degree of internationalization of the Bank of China. The share of assets of overseas institutions of the Agricultural Bank of China and the share of foreign employees are relatively low, it has the smallest coverage of countries, and net profit from foreign branches net of taxes is only $1 \%$ of the net profit of the entire bank. The total assets of 
overseas institutions of the Bank of Communications reached 855.914 billion yuan, which is $10.2 \%$ of the total assets of the group, and the net profit of foreign institutions amounted to 5.35 billion yuan, which is $7.96 \%$ of the net profit of the group. Despite the increase in assets and profits of foreign institutions, return on assets is still low. ICBC Bank has the highest results, which make up only $1.67 \%$ and $1.08 \%$ respectively [4].

The main results of foreign activities of the group of leading banks in China are presented in table 4 .

Table 4. Activities of large banks in 2017

\begin{tabular}{|c|c|c|c|c|c|c|c|c|c|}
\hline 㟐 & 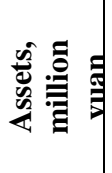 & 这 & 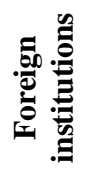 & $\frac{0}{\pi}$ & $\underset{\$}{\approx}$ & 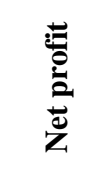 & 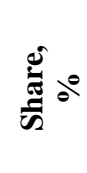 & 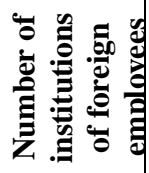 & कृ \\
\hline $\begin{array}{l}\text { Industrial and } \\
\text { commercial } \\
\text { bank of china }\end{array}$ & $\begin{array}{r}195 \\
45\end{array}$ & 8.8 & 412 & 2.4 & 1.08 & 211.3 & 7.6 & 14662 & 3.18 \\
\hline $\begin{array}{l}\text { Agricultural } \\
\text { bank of china }\end{array}$ & $\begin{array}{r}697 \\
1\end{array}$ & 3.6 & 19 & 0.08 & 0.26 & 18.05 & 1 & 788 & 0.16 \\
\hline Bank of china & $\begin{array}{r}730 \\
7 \\
\end{array}$ & 26 & 578 & 5 & 1.67 & 122.3 & 36.3 & 22509 & 7.29 \\
\hline $\begin{array}{l}\text { China } \\
\text { construction } \\
\text { bank }\end{array}$ & $\begin{array}{r}138 \\
00\end{array}$ & 6.6 & 251 & 1.63 & 0.31 & 42.47 & 1.8 & 6449 & 1.71 \\
\hline $\begin{array}{l}\text { Bank of } \\
\text { communicatio } \\
\text { ns }\end{array}$ & $\begin{array}{r}855 \\
9\end{array}$ & 10.2 & 20 & 0.6 & 0.63 & 53.5 & 8 & 2391 & 2.58 \\
\hline
\end{tabular}

Source: Annual reports of each bank

Thirdly, in the foreign business, the credit business dominates, and it is necessary to improve diversified service capabilities. The foreign institutions of Chinese banks are mainly operating institutions, and Chinese exporters are the main customers, and the degree of business simplification is relatively high. In 2017, large banks, with the exception of ABC, expanded their loan business. New loans from ICBC, BOC, and CCB reached 278.7 billion yuan, 218.1 billion yuan, and 212.5 billion yuan, respectively. The growth rate of credit balances has increased significantly, especially in China Merchants Bank, where it reaches $71.6 \%$. In accordance with the business structure, the singularity of income is also increasing. The share of commission income of foreign banks is constantly decreasing, and the gap with the general level of the group is widening. In addition, the growth rate of a foreign deposit business is usually lower than that of a foreign credit business. With the exception of BOC, overseas deposits and loans (loans / deposits) of other large banks significantly exceed 1 , which also means that the borrowed business abroad is intended for domestic funds. The degree of dependence on them is growing [5].

Fourth, the international operations of banks through international mergers and acquisitions (M\&A) are gradually becoming a trend. After years of exploration, the concept of internationalization of Chinese banks is changing, gradually moving from the creation of foreign branches and agencies to participation in capital and the acquisition of foreign banks.

In practice, until 2006, Chinese banks mainly expanded abroad, creating overseas branches. However, since 2006, the number of mergers and acquisitions, as well as their scale, has increased.

On the one hand, entering the foreign market through mergers and acquisitions can lead to a reduction in business risks. Local banks usually have a broad and stable customer base 
and business model suitable for local conditions, so rapid expansion can be achieved. On the other hand, foreign mergers and acquisitions can help get advanced business models to compensate for your own weak business or small experience. On the contrary, when creating foreign branches, Chinese banks not only face a long reporting cycle, high operating costs, but also need to address more regulatory restrictions. Thus, the M\&A method has gradually become the choice and instrument of international operations of Chinese banks. In terms of mergers and acquisitions, large commercial banks are the mainstay of overseas mergers and acquisitions, especially ICBC, CCB and BOC. They, in terms of the number of mergers and acquisitions and the amount of transactions, occupy a leading position in China. In terms of regional distribution, most of the acquisition targets are in Hong Kong, Taiwan and other large financial markets. Moreover, the goal is not limited to banking financial institutions, and in terms of the proportion of participation, Chinese banks are more prone to mergers and acquisitions [6].

Fifthly, the fight against money laundering and compliance has become more stringent, and the pressure on foreign risk management has increased significantly. As Chinese banks "go overseas," the risks and problems are even more serious. In particular, the problems of combating money laundering and compliance have already attracted the attention of the Chinese banking industry. In 2017, the ICBC Madrid branch was suspected of involvement in money laundering and tax evasion by the Spanish authorities. The ABC New York office was fined by the Regulator Bank in New York in the amount of \$ 215 million for closing transaction information. During the same period, the New York State Financial Supervisory Authority and the German Federal Financial Supervisory Authority also conducted regular or temporary inspections of some local Chinese banks. UK financial authorities have also stepped up their checks on the London branch of the CCB and the London branch of ICBC [7].

With increasing control of money laundering, the China Banking Regulatory Commission has published a "Notice of Further Strengthening the Risk Management of Overseas Operations of Banking Financial Institutions," in which Chinese banks need to incorporate country risks into the bank's stress test and formulate appropriate contingency plans for based on the results. As a result, the focus of international operations of Chinese banks will shift from business development to risk management.

\section{Conclusions}

In the presented chapter, the development of international cooperation based on innovative intellectual technologies was investigated, the prerequisites for international cooperation were identified and justified by the example of "Belt and Road", the historical necessity of the project "One belt - one way" was substantiated. The study analyzed the main indicators of the Chinese banking industry in the "Belt and Road", which allowed us to formulate the following conclusions:

1. The network of foreign branches continues to expand, and there are big differences between different types of banks.

2. Assets and profits of foreign institutions of transnational banks increased every year, but there remains a need to increase business profitability.

3 . In the foreign business, the credit business dominates, and it is necessary to improve diversified service capabilities.

4. International banking operations through international mergers and acquisitions (M\&A) are gradually becoming a trend.

5. The fight against money laundering and compliance has become more stringent, and the pressure on foreign risk management has increased significantly. 
The study was supported by a grant from the President of the Russian Federation on state support of leading scientific schools of the Russian Federation No. NSh-2702.2020.6 "Conceptual foundations of a new paradigm of economic development in the era of technological and social transformation".

\section{References}

1. O.W. Li, Global Market Information Report, 13, 37-38 (2016).

2. B. Liu, G. Zhu, Y. Lin, Money China, 34, 74-78 (2017).

3. S. Liang, New Finances, 05, 49-52 (2018)

4. S. Li, X. Liu, New Finances, 11, 12-17 (2017).

5. B. Ding, X. Fan, Rural Finance Research, 06, 50-55 (2017).

6. D. Guo, W. Li, Zhengzhou University Journal (Philosophy and Social Sciences Edition), 05, 32-36 (2018).

7. H. Oh, L. Lu, International Finance, 01, 5-8 (2017). 